Original article

\title{
PREVALENCE AND ANTIMICROBIAL SUSCEPTIBILITY OF BACTERIAL ISOLATES FROM SUBCLINICAL MASTITIS IN DAIRY FARMS IN KOSOVO
}

\author{
D. SYLEJMANI ${ }^{1}$, N. RAMADANI ${ }^{2}$, A. ROBAJ ${ }^{1} \&$ A. HAMIDI ${ }^{1}$ \\ ${ }^{1}$ Faculty of Agriculture and Veterinary, University of Prishtina, Kosovo; \\ ${ }^{2}$ National Public Health Institute, Kosovo
}

\section{Summary}

Sylejmani, D., N. Ramadani, A. Robaj \& A. Hamidi, 2016. Prevalence and antimicrobial susceptibility of bacterial isolates from subclinical mastitis in dairy farms in Kosovo. Bulg. J. Vet. Med., 19, No 4, 299-307.

The aim of this study was to determine the prevalence of subclinical mastitis in dairy cows in Kosovo and the antimicrobial susceptibility of isolated bacteria. Six hundred and twenty four milk samples from individual quarters of 156 lactating cows were tested using California Mastitis Test (CMT) and the positive samples were further analysed using conventional methods for isolation of main mastitis causing agents and finally identified using biochemical tests. The overall prevalence of subclinical mastitis was $25.6 \%$. Twenty one mastitis positive cows belonged to Holstein Friesian breed, 11 to Simmental and 8 were crossbred. Regarding age susceptibility, 13 cows resulting positive in the CMT test were 2-5 years of age and the other 27: 6-9 years of age. A total of 112 bacterial isolates were recovered. The most prevalent species were Staphylococcus aureus $(28.6 \%)$ followed by coagulase negative staphylococci (21.4\%), E. coli (13.4\%), Streptococcus agalactiae (14.3\%), Streptococcus dysgalactiae (3.6\%), Streptococcus uberis (6.2\%), Corynebacterium spp. (8\%), and Bacillus spp. $(4.5 \%)$. The isolates were subjected to antimicrobial susceptibility test using the disc diffusion method. In vitro tests of bacterial isolates revealed higher sensitivity to amoxycillin/clavulanic acid, oxytetracycline, trimethoprim and gentamicin. The lowest susceptibility was shown to penicillin and streptomycin except for Corynebacterium spp. and Bacillus spp.

Key words: bacterial pathogens, CMT, dairy cows, subclinical mastitis

\section{INTRODUCTION}

The dairy sector and especially raw milk quality in Kosovo is still not at the required level as set by the standards of current legislation. The new regulation on quality standards and grading of fresh milk came into force on January 1, 2007 (Table 1, MAFRD, 2006).
The majority of milk in the country is consumed on the farm, sold for subsistence, apart from semi-commercial farmer market it comes on the local Green Market without any prior quality control inspection. Large commercial farms which represent about $5 \%$ of the dairy market, 
mainly sell to the processors who buy milk from milk collection centers. The level of colony forming unts (CFU) and somatic cell counts (SCC) are the parameters of the milk quality according to the national standards (Bytyqi et al., 2014). Previous studies conducted on the quality of fresh milk in Kosovo have shown high CFU and SCC values, indicating high level of contamination during milking and storage of milk after milking (Bytyqi et al., 2010). About 24\% of milk collected was evaluated as being of poor hygiene, depicting values of more than 500,000 SCC cells $/ \mathrm{mL}$ and around $50 \%$ of the samples had more than 3,000,000 CFU/mL of milk in a study carried out with dairy farms in Kosovo (Bytyqi et al., 2011). The enforcement of the quality standard without intervention in milk preservation and handling infrastructure would take out of business about $90 \%$ of the dairy farmers who deliver the milk to the dairies.

The high SCC and CFU levels are associated with mastitis. It is caused by infectious agents, especially bacteria, but it can also be due to physical or chemical agents. It is a disease of dairy cattle that cause low milk production and high economic losses (Ericsson-Unnerstad et al., 2009). SCC in milk are commonly used as indicators of mastitis, on the basis that an increase reflects an immune response to the presence of infection in the mammary gland (Green et al., 2008). Although subclinical mastitis is the dominant form affecting cows, it frequently goes undetected or untreated for extended periods by most dairy producers (Hillerton \& Berry, 2003). Clinical mastitis is characterised by visible changes in milk with appearance of flakes or blobs, oedema and pain in the udder. Subclinical mastitis has been defined as inflammation without clear signs. Subclinical mastitis is a widespread disease in dairy production where every clinical case of mastitis comes along with 15 to 40 subclinical cases (Kelly et al., 2002). Several causative agents and predisposing factors have been implicated in dairy cows mastitis including bacterial, mycoplasmal and yeast pathogens. A variety of bacterial species are involved with the most common being the Gram positive staphylococci and streptococci and the Gram negative Enterobacteriaceae (Bannerman, 2009).

Approximately $70 \%$ of the antimicrobials used in dairy production are for treatment of clinical mastitis (Thomson et al., 2008), but the cure rates are not always satisfactory. The efficacy of bovine mastitis treatment depends on the cause, clinical manifestation, antibiotic suscepti-

Table 1. Standards for CFU/mL and SCC/mL according to current legislation in Kosovo (MAFRD, 2006)

\begin{tabular}{lcccc}
\hline Year & Extra class & Class I & Class II & Class III \\
\hline 2007 & $<100,000 \mathrm{CFU} / \mathrm{mL}$ & $<200,000 \mathrm{CFU} / \mathrm{mL}$ & $<500,000 \mathrm{CFU} / \mathrm{mL}$ & $>500,000 \mathrm{CFU} / \mathrm{mL}$ \\
& $<400,000 \mathrm{SCC} / \mathrm{mL}$ & $<500,000 \mathrm{SCC} / \mathrm{mL}$ & $<600,000 \mathrm{SCC} / \mathrm{mL}$ & $>600,000 \mathrm{SCC} / \mathrm{mL}$ \\
& & & & \\
\hline 2008 & $<80,000 \mathrm{CFU} / \mathrm{mL}$ & $<100,000 \mathrm{CFU} / \mathrm{mL}$ & $<200,000 \mathrm{CFU} / \mathrm{mL}$ & $<500,000 \mathrm{CFU} / \mathrm{mL}$ \\
& $<400,000 \mathrm{SCC} / \mathrm{mL}$ & $<400,000 \mathrm{SCC} / \mathrm{mL}$ & $<500,000 \mathrm{SCC} / \mathrm{mL}$ & $<600,000 \mathrm{SCC} / \mathrm{mL}$ \\
\hline 2009 & $<50,000 \mathrm{CFU} / \mathrm{mL}$ & $<80,000 \mathrm{CFU} / \mathrm{mL}$ & $<100,000 \mathrm{CFU} / \mathrm{mL}$ & \\
& $<300,000 \mathrm{SCC} / \mathrm{mL}$ & $<300,000 \mathrm{SCC} / \mathrm{mL}$ & $<400,000 \mathrm{SCC} / \mathrm{mL}$ & \\
& & & & \\
\hline
\end{tabular}


bility of etiological agent and the efficiency of immune system. The abusive or incorrect use of antimicrobials has been outlined as the major selective pressure for the development of resistance (Levy, 2002).

There is no recent data about the prevalence of subclinical and clinical mastitis and its etiological agents in Kosovo. The overall annual financial losses calculated on 50 dairy farms in Kosovo reached $€ 42,263$ per year, whilst the average annual financial loss per farm was $€ 845$ due to poor quality of milk as around $66 \%$ of all studied commercial dairy farms produced raw milk of poor quality (Musliu et al., 2009). The purpose of this survey was to investigate the prevalence and antimicrobial susceptibility of bacteria isolated from subclinical mastitis in dairy farms in some regions of Kosovo.

\section{MATERIALS AND METHODS}

This study was carried out in three regions of Kosovo (Prishtina, Prizren, Ferizaj) from January to April 2015. One hundred and fifty-six lactating cows from small holding dairy farms were screened for subclinical mastitis using CMT directly in farms with no prior mastitis control programmes in place. Regarding the breed and the age of animals, 47 cows were Friesian, 59 - crossbred and $50-$ Simmental; 70 cows were $2-5$ years of age and 86 cows: $6-9$ years of age. Cows were selected randomly from these regions with farm populations ranging from 5 to 20 cattle. Most of the farms included in the study used open and bucket machine milking, representing the typical farm size and milking practices in Kosovo. Sampling for subclinical mastitis was performed by local veterinarians. Milk was collected from individual quarters into mastitis pad- dle wells, ensuring that the first strips were discarded. The procedures and the interpretation were according to Quinn et al. (1994) using CMT test. Six hundred and twenty four milk samples from individual quarters of 156 lactating cows were tested by the CMT and only positive milk samples were collected under aseptic conditions in sterile screw-capped bottles and transported to the laboratory for isolation and identification of main mastitis bacterial pathogens. The milk samples were inoculated on 5\% sheep blood agar, MacConkey agar plates, Mannitol salt agar and Edward's agar. The plates were incubated aerobically at $37{ }^{\circ} \mathrm{C}$ for $24-48$ hours. Isolates that produced Gram positive cocci in clusters, catalase-positive, glucose-fermentative, not producing coagulase (negative coagulase reaction with rabbit plasma) were identified as coagulase negative staphylococci (CNS). Staphylococcus aureus isolates were differentiated from other coagulase-positive staphylococci ( $S$. intermedius and some $S$. hyicus strains) on the basis of mannitol fermentation on Mannitol salt agar and by using biochemical test API Staph system (BioMerieux SA). The enteric bacteria were identified on the basis of colony morphology, oxidase test, lactose fermentation on MacConkey agar, indole production test, citrate utilisation, and other standard biochemical tests as described by Quinn et al. (1994). Str. agalactiae (aesculin-negative, blue colonies) isolates were differentiated from group D streptococci (aesculin-positive, black colonies) using Edward medium while remaining streptococci were identified using the API 20 Strep strips (BioMèrieux).

All isolates were tested for antimicrobial susceptibility on Mueller Hinton agar (HIMEDIA) by disk diffusion method (CLSI, 2012). For this purpose the follow- 
Prevalence and antimicrobial susceptibility of bacterial isolates from subclinical mastitis in dairy ....

Table 2. Relationship between the incidence of subclinical mastitis and breed and age of cows

\begin{tabular}{lccc}
\hline & $\begin{array}{c}\text { Number } \\
\text { of tested cows }\end{array}$ & $\begin{array}{c}\text { Number (\%) } \\
\text { of infected cows }\end{array}$ & $\begin{array}{c}\text { Number (\%) } \\
\text { of tested/infected quarters }\end{array}$ \\
\hline Breeds of cows & & & \\
Friesian & 47 & $21(44.7)$ & $188 / 44(23.4)$ \\
Crossbred & 59 & $8(13.5)$ & $236 / 12(5.1)$ \\
Simmental & 50 & $11(22.0)$ & $200 / 20(10.0)$ \\
\hline Total & 156 & $40(25.6)$ & $624 / 76(12.2)$ \\
\hline Age of cows & & & $280 / 19(6.8)$ \\
2-5 years & 70 & $13(18.6)$ & $344 / 57(16.6)$ \\
6-9 years & 86 & $27(31.4)$ & $624 / 76(12.2)$ \\
\hline Total & 156 & $40(25.6)$ & \\
\hline
\end{tabular}

Table 3. Prevalence of subclinical mastitis in cows detected by CMT from the three studied regions

\begin{tabular}{lccc}
\hline Region & $\begin{array}{c}\text { Total number } \\
\text { of animals }\end{array}$ & $\begin{array}{c}\text { Positive animals } \\
\text { for mastitis }\end{array}$ & Prevalence \\
\hline Prishtina & 48 & 8 & $16.7 \%$ \\
Prizren & 53 & 15 & $28.3 \%$ \\
Ferizaj & 55 & 17 & $30.9 \%$ \\
\hline Total & 156 & 40 & $25.6 \%$ \\
\hline
\end{tabular}

ing antibiotic disks were used: penicillin $\mathrm{P}$ (10 IU, Oxoid), amoxicillin/clavulanic acid AMC (30 $\mu \mathrm{g}$, Oxoid), oxytetracycline $\mathrm{T}\left(30 \mu \mathrm{g}, \mathrm{BD} \mathrm{BBL}^{\mathrm{TM}}\right)$, streptomycin S (10 $\mu \mathrm{g}$, Liofilchem), cloxacillin CX $(5 \mu \mathrm{g}$, Liofilchem), gentamicin $\mathrm{CN}(10 \mu \mathrm{g}$, Liofilchem), trimethoprim TM (2.5 $\mu \mathrm{g}$, Liofilchem).

The plates were incubated at $35^{\circ} \mathrm{C}$ for 24 hours. The zone of inhibition around each disc was measured and the interpretation was made as per the zone size interpretation chart provided by the disc manufacturer.

\section{RESULTS}

In the CMT, 156 lactating cows from 32 farms (624 foremilk quarter samples) were tested for subclinical mastitis. In total, $40(25.6 \%)$ cows and $76(12.2 \%)$ quarters were diagnosed with subclinical mastitis. Regarding breed susceptibility, out of the 40 cows positive for subclinical mastitis by CMT, 21 were Holstein Friesian $(44.7 \%), 11$ were Simmental $(22 \%)$ and 8 were crossbred (13.5\%) (Table 2). As shown in Table 2, the prevalence of subliclinical mastitis was higher in cows aged $6-9$ years $(31.4 \%)$ than in those aged $2-5$ years $(18.6 \%)$.

The prevalence of mastitis in three regions is given in Table 3 . Out of 76 positive milk samples, a total of 112 different bacterial isolates were isolated and the biochemical tests identified 8 species as shown in Table 4. The results of this study showed that the most predominant species were $S$. aureus $(\mathrm{n}=32 ; 28.6 \%)$, followed by CNS $(\mathrm{n}=24 ; 21.4 \%)$, E. coli $(\mathrm{n}=15$ or 
Table 4. Bacterial isolates from milk samples of the cows with subclinical mastitis in the three studied regions in Kosovo

\begin{tabular}{lc}
\hline Bacterial isolates & $\begin{array}{c}\text { Number } \\
(\%)\end{array}$ \\
\hline Staphylococcus aureus & $32(28.6)$ \\
Coagulase negative staphy- & $24(21.4)$ \\
lococci (CNS) & \\
E. coli & $15(13.4)$ \\
Streptococcus agalactiae & $16(14.3)$ \\
Streptococcus dysgalactiae & $4(3.4)$ \\
Streptococcus uberis & $7(6.2)$ \\
Corynebacterium spp. & $9(8)$ \\
Bacillus spp. & $5(4.5)$ \\
\hline Total & $112(100)$ \\
\hline
\end{tabular}

13.4\%), Str. agalactiae $(\mathrm{n}=16 ; 14.3 \%)$ Corynebacterium spp. $(\mathrm{n}=9 ; 8 \%)$, and Bacillus spp. $(\mathrm{n}=5 ; 4.5 \%)$.
The antimicrobial susceptibility and resistance profiles of bacterial isolates from subclinical cases of mastitis to antibiotics are shown in Table 5. In this study, $S$. aureus isolates were found to be highly susceptible to amoxicillin/clavulanic acid $(90.6 \%)$, followed by oxytetracycline (78.1\%), trimethoprim (75\%) and gentamicin $(71.9 \%)$. However these isolates were highly resistant to penicillin (71.9\%), streptomycin $(75 \%)$ and cloxacillin $(53.1 \%)$. Coagulase negative staphylococci were also more sensitive to amoxycillin/clavulanic acid (83.3\%), trimethoprim $(79.2 \%)$, oxytetracycline $(75 \%)$, gentamicin $(62.5 \%)$, cloxacillin $(54.2 \%)$. E. coli (13.4\% of all isolates) were highly susceptible to oxytetracycline $(86.7 \%)$, trimethoprim $(80 \%)$, gentamicin $(66.7 \%)$, cloxacillin $(53.3 \%)$ but not to amoxicillin/clavulanic acid $(20 \%)$. None of the

Table 5. Antimicrobial susceptibility of bacterial isolates from cows with subclinical mastitis to antibiotics - percentage of sensitive $(\mathrm{S})$ and resistant $(\mathrm{R})$ isolates

\begin{tabular}{|c|c|c|c|c|c|c|c|c|}
\hline \multirow{2}{*}{ Bacterial isolates } & & \multicolumn{7}{|c|}{ Tested antimicrobial drugs } \\
\hline & & AM/CLA & OXY & CLO & GEN & TRI & PEN G & STR \\
\hline \multirow{2}{*}{$\begin{array}{l}\text { S. aureus } \\
(n=32)\end{array}$} & $\mathrm{S}$ & 90.6 & 78.1 & 46.9 & 71.9 & 75 & 28.1 & 25 \\
\hline & $\mathrm{R}$ & 9.4 & 21.9 & 53.1 & 28.1 & 25 & 71.9 & 75 \\
\hline \multirow{2}{*}{$\begin{array}{l}\mathrm{CNS} \\
(n=24)\end{array}$} & $\mathrm{S}$ & 83.3 & 75 & 54.2 & 62.5 & 79.2 & 25 & 41.7 \\
\hline & $\mathrm{R}$ & 16.7 & 25 & 45.8 & 37.5 & 20.8 & 75 & 58.3 \\
\hline \multirow{2}{*}{$\begin{array}{l}\text { E. coli } \\
(n=15)\end{array}$} & $\mathrm{S}$ & 80 & 86.7 & 53.3 & 66.7 & 80 & 20 & 26.7 \\
\hline & $\mathrm{R}$ & 20 & 13.3 & 46.7 & 33.3 & 20 & 80 & 73.3 \\
\hline \multirow{2}{*}{$\begin{array}{l}\text { S. agalactiae } \\
(n=16)\end{array}$} & $\mathrm{S}$ & 93.75 & 75 & 81.25 & 68.75 & 87.5 & 56.25 & 62.5 \\
\hline & $\mathrm{R}$ & 6.25 & 25 & 18.75 & 31.25 & 12.5 & 43.75 & 37.5 \\
\hline \multirow{2}{*}{$\begin{array}{l}\text { S. dysgalactiae } \\
(n=4)\end{array}$} & $\mathrm{S}$ & 100 & 75 & 50 & 75 & 100 & 25 & 25 \\
\hline & $\mathrm{R}$ & - & 25 & 50 & 25 & - & 75 & 75 \\
\hline \multirow{2}{*}{$\begin{array}{l}\text { S. uberis } \\
(n=7)\end{array}$} & $S$ & 85.7 & 57.1 & 85.7 & 71.4 & 57.1 & 28.6 & 28.6 \\
\hline & $\mathrm{R}$ & 14.3 & 42.9 & 14.3 & 28.6 & 42.9 & 71.4 & 71.4 \\
\hline \multirow{4}{*}{$\begin{array}{l}\text { Corynebacterium } \\
\text { spp. }(n=9) \\
\text { Bacillus spp. } \\
(n=5)\end{array}$} & $\mathrm{S}$ & 77.8 & 88.9 & 66.7 & 77.8 & 88.9 & 66.7 & 66.7 \\
\hline & $\mathrm{R}$ & 22.2 & 11.1 & 33.3 & 22.2 & 11.1 & 33.3 & 33.3 \\
\hline & S & 80 & 60 & 80 & 80 & 80 & 80 & 60 \\
\hline & $\mathrm{R}$ & 20 & 40 & 20 & 20 & 20 & 20 & 40 \\
\hline
\end{tabular}

Legend: AM/CLA: amoxillin/clavulanic acid; OXY: oxytetracycline; CLO: cloxacillin; GEN: gentamicin; TRI trimethoprim; PEN G: penicillin G; STR: streptomycin. 
four Str. dysgalactiae isolates was resistant to amoxicillin/clavulanic acid and trimethoprim.

\section{DISCUSSION}

In the present study, the prevalence of subclinical mastitis was $25.6 \%$ as measured on a cow basis, and $12.2 \%$ as measured on a quarter basis. This prevalence rate is relatively high, although substantially higher values have been also reported, for instance the incidence of subclinical mastitis in Uruguay was $52.4 \%$ as measured on a cow basis and $26.7 \%$ on a quarter basis (Gianneechini et al., 2002). The CMT results in the present study showed that the prevalence of subclinical mastitis at cow level was higher in Holstein Friesian $(44.7 \%)$ than in the Simmental $(22 \%)$ and crossbred cows $(13.5 \%)$. This might be primarily in association with genetic resistance and also with poor adaptation of these cows to local environment and climate (Girma, 2001; Dego \& Tarek, 2003), but future studies are needed to explain different udder infection rates in cow breeds. Regarding age susceptibility, higher percentage of subclinical mastitis was established in cows aged $6-9$ years $(31.4 \%)$ than in those aged $2-5$ years $(18.6 \%)$. This agerelated variation in the prevalence of subclinical mastitis is attributed to the fact that cows with multiple parturitions are more prone to mastitis than younger cows due to physical alterations of udder, and is in line with findings reported by other authors (Carlen et al., 2004; Zwald et al., 2004; Abdel-Rady et al., 2009). This occurrence could be in association with differences in management systems between farms, stage of lactation, parity, breed (Almaw et al., 2008) and milking hygiene (Haltia et al., 2006).
The most commonly isolated pathogens in our study were $S$. aureus with a frequency of $28.6 \%$, followed by CNS: $21.4 \%, S$. agalactiae: $14.3 \%$, and E. coli: $13.4 \%$. In previous studies, $S$. aureus was also reported as major pathogen (Rabello et al., 2005; Botrel et al., 2009). The present study showed that staphylococci and streptococci represented more than half (73.9\%) of bacterial isolates involved in subclinical mastitis, followed by other bacteria. Similar results were also reported in Italy (Moroni et al., 2006). Bacteria that most frequently cause mastitis can be classified into two main categories major and minor pathogens (Sargeant et al., 2001). S. aureus, Str. agalactiae and $E$. coli are the most common etiological agents involved in subclinical and clinical cases of mastitis in dairy cows (Gonzalo et al., 2002). The high rate of isolation of staphylococci may be attributed to the fact that the principal reservoirs of these organisms are the udder skin and milk of the infected gland. The high frequency of staphylococcal mastitis is considered to be due to the existence of inadequate hygiene in the dairy industry, poor animal health services, and lack of proper attention to the health of the mammary gland in general.

The antimicrobial susceptibility tests carried out in this study show in general a high susceptibility for $S$. aureus to amoxicillin/clavulanic acid $(90.6 \%)$, oxytetracycline $(78.1 \%)$, trimethoprim $(75 \%)$ and gentamicin $(71.9 \%)$ and resistance to streptomycin $(75 \%)$, penicillin G $(71.9 \%)$ and cloxacillin $(53.1 \%)$. The majority of authors have noted an increase in the resistance to antibiotics of bacteria, mostly staphylococci, isolated from mastitis (Pitkala et al., 2004; Turutoglu et al., 2006; Pyorala \& Taponen, 2009). During this study the data were collected from local 
veterinarians on antibiotics most frequently used for the treatment of clinical mastitis in cows. Antimicrobials such as penicillin+streptomycin (PENSTREP 20/ 20 administered by parenteral routes), oxytetracycline (ALAMYCIN $100 \mathrm{mg} / \mathrm{mL}$, Limoxin 100, TOPOXY 10, administered by parenteral routes), procaine benzylpenicillin+streptomycin sulphate+neomycin sulphate (Mastiquick $5 \mathrm{~g}$ intramammary injector), colistin sulphate+ metampicillin sodium+cloxacillin sodium (Mastidian forte $10 \mathrm{~mL}$ intramammary injector) were used most often in cases of clinical mastitis in lactating cows in these regions and very rarely, sulfadiazine+trimethoprim (Norodine 24 administered by parenteral routes).

The present study revealed higher sensitivity for $S$. agalactiae, S. dysgalactiae, $S$. uberis, Corynebacterium spp. and Bacillus spp. to the same antibiotics as amoxicillin/clavulanic acid, oxytetracycline, trimethoprim, gentamicin and cloxacillin, except for Str. dysgalactiae and Str. uberis isolates that were more resistant to penicillin and streptomycin. None of Str. dysgalactiae isolates was resistant to amoxicillin/clavulanic acid and trimethoprim which shows the efficacy of these antibiotics in treatment of mastitis. Idriss et al. (2014) has found that Str. agalactiae, Str. uberis, S. aureus, CNS and $E$. coli were sensitive to amoxicillin/clavulanic acid, which support our findings but the other antibiotics in our case showed different results which might have different association.

In conclusion, this study provides the proof about a very high prevalence of subclinical mastitis on dairy farms in three Kosovo regions (25.6\%). The most commonly isolated pathogens were $S$. aureus, followed by coagulase negative staphylococci (CNS), Str. agalactiae, and E. coli.
The antimicrobial susceptibility tests shows higher susceptibility of $S$. aureus, CNS, E. coli, Str. agalactiae, Str. dysgalactiae, Str. uberis, Corynebacterium spp., and Bacillus spp., to amoxicillin/ clavulanic, oxytetracycline and trimethoprim. Good management practices and routine tests with CMT can help for early detection of infection and reduction of subclinical mastitis prevalence. Identification of mastitis pathogens and antimicrobial susceptibility testing are essential to control the disease, achieve effective therapy and consequently improve the farm profitability.

\section{ACKNOWLEDGMENTS}

The authors thank the Dairy Farmers Association "Grauvieh", Kosovo for the access to the farms, support on samplings and sample transportation as well as local veterinarians in the region of Central and Southwest Kosovo.

\section{REFERENCES}

Abdel-Rady, A. \& M. Sayed, 2009. Epidemiological studies on subclinical mastitis in dairy cows in Assiut governorate. Veterinary World, 2, 373.

Almaw, G., A. Zerihun \& Y. Asfaw, 2008. Bovine mastitis and its association with selected risk factors in smallholder dairy farms in and around Bahir Dar, Ethiopia. Tropical Animal Health and Production, 40, 427-432.

Bannerman, D. D., 2009. Pathogen-dependent induction of cytokines and other soluble inflammatory mediators during intramammary infection of dairy cows. Journal of Animal Science, 87, 10-25.

Botrel, M. A., M. Haenni, E. Morignat, P. Sulpice, J. Y. Madec \& D. Calavas, 2009. Distribution and antimicrobial resistance of clinical and subclinical mastitis pathogens in dairy cows in Rhône-Alpes, Fran- 
Prevalence and antimicrobial susceptibility of bacterial isolates from subclinical mastitis in dairy ....

ce. Foodborne Pathogens and Diseases, 7 , $479-487$.

Bytyqi, H, U. Zaug, K. Sherifi, A. Hamidi, M. Gjonbalaj, S. Muji \& H. Mehmeti, 2010. Somatic cell count and quality of fresh milk in Kosova related to existing standards. Veterinarski Arhiv, 80, 173-183.

Bytyqi, H., S. Bigler, S. Muji, A. Jahja \& U. Zaugg, 2011. Survey on raw milk quality in Kosovo. Food and Nutrition Sciences, 2, 414-421.

Bytyqi, H., P. Ruegg, F. Rrustemaj, P. Kastrati \& S. Wells, 2014. A study of the somatic cell count of Kosovo bulk milk farm management and perspective. Albanian Journal of Agriculture Science, 13, 317-323.

Carlen, E., E. Strandberg \& A. Roth, 2004. Genetic parameters for clinical mastitis, somatic cell score, and production in the first three lactations of Swedish Holstein cows. Journal of Dairy Science, 87, 3062 3070.

Dego, O. K. \& F. Tareke, 2003. Bovine mastitis in selected areas of southern Ethiopia. Tropical Animal Health and Production, 35, 197-205.

Ericsson Unnerstad, H., A. Lindberg, K. Persson Waller, T. Ekman, K. Arturson, M. Nilsson-Öst \& B. Bengtsson, 2009. Microbial aetiology of acute clinical mastitis and agent-specific risk factors. Veterinary Microbiology, 137, 90-97.

Gianneechini, R., C. Concha, R. Rivero, I. Delucci \& J. Moreno-Lopez, 2002. Occurrence of clinical and sub-clinical mastitis in dairy herds in the west littorial region in Uruguay. Acta Veterinaria Scandinavica, 43, 221-230.

Girma, T., 2001. Prevalence of mastitis at Alemaya University dairy farm. Journal of the Ethiopian Veterinary Association, 5, 17-21.

Gonzalo, C., A. Ariznabarrta \& J. A. Carriedo, 2002. Mammary pathogens and their relationship to somatic cell count and milk yield losses in dairy ewes. Journal of Dairy Science, 85, 1460-1467.
Green, M. J., A. J. Bradley, G. F. Medley \& W. J. Browne, 2008. Cow, farm, and herd management factors in the dry period associated with raised somatic cell counts in early lactation. Journal of Dairy Science, 91, 1403-1415.

Idriss, Sh. E., V. Foltys, V. Tancin, K. Kirchnerova, D. Tancinova \& K. Zaujec, 2014. Mastitis pathogens and their resistance against antimicrobial agents in dairy cows in Nitra, Slovakia. Slovak Journal of Animal Science, 47, 33-38.

Haltia, L., T. Honkanen-Buzalski, I. Spiridonova, A. Olkonen \& V. Myllys, 2006. A study of bovine mastitis, milking procedures and management practices on 25 Estonian dairy herds. Acta Veterinaria Scandinavica, 48, 22.

Hillerton, J. E. \& E. A. Berry, 2003. The management and treatment of environmental streptococcal mastitis. Veterinary Clinics of North America: Food Animal Practice, 19, 157-169.

Kelly, A. L., 2002. Test methods and standards. In: Encyclopedia of Dairy Sciences, Academic Press, London, pp. 1995-2002.

Levy, S. B., 2002. The antibiotic paradox: How the misuse of antibiotics destroys their curative powers, $2^{\text {nd }}$ edn, International Microbiology, 5, 155-156.

MAFRD (Ministry of Agriculture, Forestry and Rural Development), 2006. Administrative Instruction MA-No. 20/2006 on Quality Standards and grade of fresh Milk. http://www.mbpzhr-ks.net/en/administrative-instructions/?dy $=2006 \&$ offset $=0$ April 2015, date last acccesed).

Musliu, A., M. Gjonbalaj, K. Sharifi \& M Meqe, 2009. Economic losses related to raw milk quality on commercial dairy farms in Kosovo. New Medit, 8, 49-53.

Moroni, P., G. Pisoni, M. Antonini, R. Villa, P. Boettcher \& S. Carli, 2006. Antimicrobial drug susceptibility of Staphylococcus aureus from subclinical bovine mastitis in Italy. Journal of Dairy Science, 89, 29732976. 
Pitkälä, A., M. Haveri, S. Pyörälä, V. Myllys \& T. Hankonen-Buzalski, 2004. Bovine mastitis in Finland 2001 - prevalence, distribution of bacteria and antimicrobial resistance. Journal of Dairy Science, 87, 2433-2441.

Pyörälä, S. \& S. Taponen, 2009. Coagulasenegative staphylococci-emerging mastitis pathogens. Veterinary Microbiology, 134, 3-8.

Quinn, P. J., M. E. Carter, B. K. Markey \& G. R. Carter, 1994. Clinical Veterinary Microbiology. Mosby-Year Book, Europe limited, London.

Rabello, R. F., C. R. V. M. Souza, R. S. Duarte, R. M. M. Lopez, L. M. Teixeira \& A. C. D. Castro, 2005. Characterization of Staphylococcus aureus isolates recovered from bovine mastitis in Rio de Janeiro, Brazil. Journal of Dairy Science, 88, 3211-3219

Sargeant, J. M., K. E. Leslie, J. E. Shirley, B. J. Pulkrabek \& G. H. Lim, 2001. Sensitivity and specificity of somatic cell count and California Mastitis Test for identifying intramammary infection in early lactation. Journal of Dairy Science, 84, 2018-2024.

Turutoglu, H., S. Ercelik \& D. Ozturk, 2006. Antibiotic resistance of Staphylococcus aureus and coagulase-negative staphylococci isolated from bovine mastitis. Bulletin of Veterinary Institute in Pulawy, 50, 41-45.
Thomson, K., M. Rantala, M. Hautala, S. Pyörälä \& L. Kaartinen, 2008. Crosssectional prospective survey to study indication-based usage of antimicrobials in animals: Results of use in cattle. $B M C \mathrm{Ve}-$ terinary Research, 4, 15.

Zwald, N. R., K. A. Weigel, Y. M. Chang, R. D. Welper \& J. S. Clay, 2004. Genetic selection for health traits using producerrecorded data. II. Genetic correlations, disease propabilities, and relationships with existing traits. Journal of Dairy Science, 87, 4295-4302.

Paper received 25.06.2015; accepted for publication 25.09.2015

\section{Correspondence:}

Dr. sc. Afrim Hamidi, Prof. Asc., Faculty of Agriculture and Veterinary, University of Prishtina, Bill Clinton Blvd 10000 Prishtina, Kosovo e-mail: afrim.hamid@uni-pr.edu 